\title{
Effects of oregano essential oil and attapulgite on growth performance, intestinal microbiota and morphometry in broilers
}

\author{
I. Skoufos ${ }^{1}$, I. Giannenas ${ }^{2 \#}$, D. Tontis ${ }^{3}$, T. Bartzanas ${ }^{4}$, C. Kittas ${ }^{5}$, \\ P. Panagakis ${ }^{6} \&$ A. Tzora $^{1}$ \\ ${ }^{1}$ Department of Agriculture Technology, School of Agriculture Technology, Food Technology and Nutrition, \\ Division of Animal Production, TEl of Epirus, 47100, Arta, Greece \\ ${ }^{2}$ Laboratory of Nutrition, Faculty of Veterinary Medicine, School of health Science, \\ Aristotle University of Thessaloniki, 54124, Thessaloniki, Greece \\ ${ }^{3}$ Laboratory of Pathology, Faculty of Veterinary Medicine, School of Health Science, University of Thessaly, \\ 43100, Karditsa, Greece \\ ${ }^{4}$ Department of Agriculture Crop Production and Rural Environment, School of Agricultural Sciences, \\ University of Thessaly, 38446, N. Ionia, Magnisia, Greece \\ ${ }^{5}$ Centre for Research and Technology - Hellas- Institute for Research and Technology-Thessaly, 38333, Volos, Greece \\ ${ }^{6}$ Laboratory of Farm Structures, Department of Natural Resources Management \& Agricultural Engineering, Agricultural \\ University of Athens, lera Odos 75, Athens 11855, Greece
}

(Received 6 July 2015; Accepted 3 February 2016; First published online 21 March 2016)

\author{
Copyright resides with the authors in terms of the Creative Commons Attribution 2.5 South African Licence. \\ See: http://creativecommons.org/licenses/by/2.5/za \\ Condition of use: The user may copy, distribute, transmit and adapt the work, but must recognise the authors and the South African \\ Journal of Animal Science.
}

\begin{abstract}
Two experiments were conducted to study the effects of a blend of oregano essential oil (OEO) (as a source of natural antibacterial growth-promoting substances) and attapulgite (as a source of toxin-binder and as an antidiarrhoeal agent) on growth performance, intestinal microbiota, and intestinal morphometry in broiler chickens (Ross-308). In the first trial, the control group was fed a basal diet without antibiotic growth promoters, and the experimental group was fed the basal diet supplemented with $5 \%$ OEO (OEO) (Ecodiar ${ }^{\circledR}$ powder at $150 \mathrm{~g} / \mathrm{tn}$ ) and $80 \%$ attapulgite $80 \%$ (Ultrafed $^{\circledR}$ at $6 \mathrm{~kg} / \mathrm{tn}$ ) blend. In the second trial, the experimental group was given the basal diet supplemented with $5 \%$ OEO (Ecodiar ${ }^{\circledR}$ powder at $300 \mathrm{~g} / \mathrm{tn}$ ) and $80 \%$ attapulgite (Ultrafed ${ }^{\circledR}$ at $3 \mathrm{~kg} / \mathrm{tn}$ ) blend. Intestinal microbiota was enumerated by conventional techniques with selective agar media at the end of the trial at both ileum and caecum, and intestinal morphology was assessed in the duodenum, jejunum and ileum. Results showed that in the first trial, despite the positive impact on daily gain and feed-to-gain ratio, growth performance was not affected by the blend with OEO and attapulgite. Furthermore, no effect was found on intestinal morphometry. However, the counts of lactic acid bacteria were increased significantly, and coliforms were decreased in caecal contents. In the second trial, a positive impact was noticed on daily gain and feed-to-gain ratio by the high OEO and low attapulgite blend. Dietary supplementation of OEO and attapulgite increased ileal villus height and lactic acid bacteria significantly and reduced coliforms in ileal and caecal contents compared with the control group. In conclusion, the combination of OEO at $15 \mathrm{mg} / \mathrm{kg}$ and attapulgite at $2.4 \mathrm{~g} / \mathrm{kg}$ exerted a positive effect on growth performance, ileal villus height and intestinal microbiota of broilers.
\end{abstract}

Keywords: Gut microflora, intestinal architecture, magnesium aluminium silicate, oregano

\#Corresponding author: igiannenas@vet.auth.gr

\section{Introduction}

Antibiotics fed at sub-therapeutic levels have been widely used as the cornerstone of increased performance with improved growth rate and feed efficiency in broiler chickens, as well as health improvement with reduced morbidity and mortality (Castanon, 2007), and several positive effects specifically related to gut health. However, owing to the development of bacteria strains that are resistant to antibiotics (Pratt et al., 2003), this use has been questioned. European Union (EU) countries were the first to ban antibiotic growth promoters. Several other countries have put restrictions on the use of in-feed antibiotics. Suggestions for restrictions or even a ban on the use of antibiotics as feed additives might eventually come 
to American and Asian countries (Clark et al., 2012) owing to increased concern about the transmission and proliferation of bacteria resistance via the food chain.

This restriction on the use of antibiotics has prompted nutritionists and feed manufacturers to develop alternative feed additives to promote growth, strengthen the immune system and sustain the health of broiler chickens because of increased concern over food safety, environmental contamination and general health risks (Wegener et al., 1998). Therefore, considerable efforts have been devoted towards developing alternatives to antibiotics. Historically humankind used aromatic plants, herbs, spices and their extracts thousands of years ago in Mesopototamia, Egypt, India, China and Ancient Greece for their aroma and medicinal properties. Nowadays, plant extracts and especially essential oils could be exploited as a new class of feed additives. Despite the start of their use in animal nutrition several decades ago (Vogt et al., 1989), knowledge of their modes of action and aspects of application is rudimentary (Windisch et al., 2008; Franz et al., 2010; Giannenas et al., 2013; Zeng et al., 2015).

Numerous studies have documented the benefits of essential oils to the performance of poultry (Brenes \& Roura, 2010; Franz et al., 2010; Giannenas et al., 2014a; b). Windisch et al. (2008) reviewed 11 papers on poultry and reported that the average changes in weight gain, feed intake and feed conversion induced by essential oils were $0.5,-1.6$ and $-2.6 \%$, respectively. Aromatic herbs and essential oils are often claimed to improve the flavour and palatability of feed, thus increasing voluntary feed intake, and resulting in improved weight gain. However, in a choice feed experiment conducted in growing chickens by Symeon et al. (2010), the classification of oregano essential oil (OEO) as a flavour additive or as an 'appetite promoter' in chicken diets was questioned. Another important consideration is the stability of essential oils during feed processing. Maenner et al. (2011) reported considerable loss of activity of essential oils when a pelleting temperature of $58^{\circ} \mathrm{C}$ was applied.

Natural zeolites have been investigated extensively over the last decade, because of the good performance of these materials in ion exchange. They have negative charges on their surfaces, which enable them to be modified by cationic surfactants, to enhance contaminant retention and to retard contaminant migration, together with high chemical stability (Lam \& Rivera, 2006; Kaya et al., 2013).

Attapulgite is a layered magnesium aluminium silicate and its unique structure confers the properties of absorption of pathogenic bacteria and toxins and enables it to be used in animal nutrition as antidiarrhoeal agent (Pappas et al., 2010). Because Origanum vulgare L. subsp. hirtum extracts are used widely in broilers for their antibacterial, coccidiostatical and anti-inflammatory activity, and as a natural growth promoting substance (Giannenas et al., 2013), a combination with attapulgite might offer protection to OEO, good distribution and enhancement of its activity. Information on the dietary use of attapulgite is limited, and there is no information about the combination of attapulgite and OEO, especially at various supplementation levels. The aim of the current study therefore was to investigate the effects of OEO and attapulgite supplementation at two inclusion levels on performance, intestinal microflora and intestinal morphometry of chickens.

\section{Materials and Methods}

Two experiments were conducted at commercial broiler chicken farms in Epirus, Greece. The trial protocol was approved by the Institutional Committee for Animal Use and Ethics of the Technological Institute of Epirus, Department of Animal Production. Throughout the trials, the birds were handled in compliance with local laws and regulations and in accordance with the principles and guidelines for poultry welfare according to the National Research Council (NRC, 1996). All groups were housed on rice hull litter. The stocking density was 17 birds per $\mathrm{m}^{2}$. During the trial, commercial breeding and management procedures were employed, and natural and artificial light were provided on a basis of $23 \mathrm{~h}$ for the first two days; 16 hours from day 3 to day 14; and $21 \mathrm{~h}$ from day 15 to the slaughter day. The ambient temperature was controlled. All birds were vaccinated against Marek disease after hatching, and against Newcastle disease, Infectious Bronchitis on day 12 and Gumboro on day 14 of their lives. Feed and drinking water were offered to all birds ad libitum throughout the experiment. All birds from each replicate were weighed individually at the time of placing in the poultry house and then every week. Feed consumption in each group was recorded during the experimental period and feed conversion ratio (FCR) was calculated finally. Mortality was recorded daily.

The first trial was conducted in Ioannina $\left(39^{\circ} 39^{\prime} 16^{\prime \prime} \mathrm{N} ; 20^{\circ} 50^{\prime} 34^{\prime \prime E}\right)$, Epirus, Greece. Three hundred broiler chickens, as hatched (Ross-308), were divided into two groups (control vs. blend of OEO and attapulgite) with three replicates, and reared for 44 days at a commercial farm (Pindos Agricultural Poultry Cooperative, Ioannina). The blend group received the basal diet supplemented with $5 \%$ OEO Ecodiar ${ }^{\circledR}$ powder at $150 \mathrm{~g} / \mathrm{tn}$ ) and $80 \%$ attapulgite (Ultrafed ${ }^{\circledR}$ at $6 \mathrm{~kg} / \mathrm{tn}$ ). The composition of the basal diet (mash form) for the first trial is presented in Table 1. Feed formulation was carried out according to NRC (1994) 
recommendations. The main constituents of OEO oil as provided by the supplier were $81.02 \%$ carvacrol $81.02 \%, 5.42 \%$ p-cymene, $4.65 \%$ y-terpinene and 3.02\% thymol.

Table 1 Composition of basal diets (Trial 1)

\begin{tabular}{|c|c|c|c|c|}
\hline \multirow{2}{*}{ Ingredients, $\mathbf{g} / \mathbf{k g}$} & \multicolumn{4}{|c|}{ Control diet at different growth stages } \\
\hline & $1-14 d$ & $15-28 d$ & $29-35 d$ & $36-44 d$ \\
\hline Wheat & 481 & 522 & 550 & 550 \\
\hline Maize & 120 & 100 & 80 & 80 \\
\hline Soybean meal, $47.4 \%$ & 336 & 306 & 292 & 292 \\
\hline Soybean oil & 25 & 25 & 25 & 25 \\
\hline Coconut fat & - & 15 & 25 & 25 \\
\hline Limestone & 12 & 11 & 10 & 10 \\
\hline Dicalcium phosphate & 11 & 9 & 7 & 7 \\
\hline L-lysine, hydrochloride & 3.5 & 3 & 2.5 & 2.5 \\
\hline DL-methionine & 3 & 1.5 & 1.5 & 1.5 \\
\hline Sodium bicarbonate & 2 & 1 & 1 & 1 \\
\hline Salt & 2.5 & 2.5 & 2.0 & 2.0 \\
\hline $\begin{array}{l}\text { Vitamins and mineral, enzyme } \\
\text { premix }^{1}\end{array}$ & 4 & 4 & 4 & 4 \\
\hline \multicolumn{5}{|l|}{ Nutrients (calculated analysis) } \\
\hline Metabolizable energy, MJ/kg & 12.98 & 13.31 & 13.48 & 13.48 \\
\hline Crude protein, g/kg & 220 & 210 & 200 & 200 \\
\hline Ether extract, g/kg & 62 & 66 & 68 & 68 \\
\hline Crude fibre, g/kg & 35 & 36 & 37 & 37 \\
\hline Ash, g/kg & 47 & 46 & 46 & 46 \\
\hline Calcium, g/kg & 10 & 9 & 8 & 8 \\
\hline Total phosphorus, g/kg & 7 & 6 & 6 & 6 \\
\hline Lysine, $\mathrm{g} / \mathrm{kg}$ & 13 & 12 & 11 & 11 \\
\hline Methionine + cystine, $\mathrm{g} / \mathrm{kg}$ & 10 & 9.6 & 9.4 & 9.4 \\
\hline
\end{tabular}

\footnotetext{
${ }^{1}$ Supplying per $\mathrm{kg}$ of feed: $12000 \mathrm{IU}$ vitamin $\mathrm{A} ; 5000 \mathrm{IU}$ vitamin $\mathrm{D}_{3} ; 80 \mathrm{mg}$ vitamin $\mathrm{E} ; 7 \mathrm{mg}$ vitamin $\mathrm{K} ; 5 \mathrm{mg}$ thiamine; $6 \mathrm{mg}$ riboflavin; $6 \mathrm{mg}$ pyridoxine; $0.02 \mathrm{mg}$ vitamin $\mathrm{B}_{12} ; 60 \mathrm{mg}$ niacin; $15 \mathrm{mg}$ pantothenic acid; $1.5 \mathrm{mg}$ folic acid: 0.25 biotin; 10 mg vitamin C; 500 mg choline chloride; 100 mg Zn; 120 mg Mn; 20 mg Fe; 15 mg Cu; 0.2 mg Co; $1 \mathrm{mg} \mathrm{l} ; 0.3 \mathrm{mg}$ Se and phytase and xylanase in recommended quantities per $\mathrm{kg}$ of diet.
}

The second trial was conducted at Arta $\left(39^{\circ} 09^{\prime} 38^{\prime \prime} \mathrm{N} ; 2^{\circ} 59^{\prime} 07^{\prime \prime E}\right)$, Epirus, Greece. Three hundred broiler chickens, as hatched (Ross-308), were divided into two groups (control vs. blend of OEO and attapulgite) with three replicates, and reared for 42 days at a commercial farm (Agricultural Poultry Farmer Cooperative, Arta). The blend group received the basal diet supplemented with $5 \%$ OEO (Ecodiar ${ }^{\circledR}$ powder at $300 \mathrm{~g} / \mathrm{tn}$ ) and $80 \%$ attapulgite (Ultrafed ${ }^{\circledR}$ at $3 \mathrm{~kg} / \mathrm{tn}$ ). The composition of the basal diet (mash form) for the second trial is presented in Table 2.

At the end of the trial, 18 chickens from each group were killed by cervical dislocation. The contents of the crop, gizzard, ileum, caeca and rectum were collected quantitatively. The digesta from each gastrointestinal tract (GIT) from three birds were randomly pooled to obtain three replicates. The ileum was defined as the small intestinal segment caudal to Meckel's diverticulum. The rectum was defined as the segment from the ileo-caecal junction to the end of the GIT. The pH in the contents of all gastrointestinal segments was measured with a combined glass/reference electrode portable pH meter BT-600 (BOECO, Germany).

To determine bacterial populations, fresh weighed digesta samples from the ileum and caecum were mixed homogeneously at a ratio of $1 \mathrm{~g}$ sample to $9 \mathrm{~mL}$ of peptone water $(0.1 \% \mathrm{v} / \mathrm{v})$ in the universal bottle for 
bacterial enumeration, such as total aerobes, total anaerobes, Lactobacilli spp. and total coliforms by conventional microbiological techniques using selective agar media in 18 chickens from each group. Subsequently, serial decimal dilutions were made, avoiding aeration, using the medium as described previously (Giannenas et al., 2011). The samples were plated on de Man Rogosa Sharpe (MRS) agar to determine lactobacilli, and incubated under anaerobic conditions at $37^{\circ} \mathrm{C}$ for $48 \mathrm{~h}$. Samples were incubated under aerobic conditions at $37^{\circ} \mathrm{C}$ for $24 \mathrm{~h}$ on MacConkey agar to determine total coliform numbers. This process was repeated and the results were expressed as colony forming unit (CFU) per gram of sample (CFU/g).

Table 2 Composition of basal diets (Trial 2)

\begin{tabular}{|c|c|c|c|c|}
\hline \multirow{2}{*}{ Ingredients, g/kg } & \multicolumn{4}{|c|}{ Control diet at different growth stages } \\
\hline & $1-14 d$ & $15-28 d$ & $29-35 d$ & $36-4 d$ \\
\hline Wheat & 464 & 500 & 527 & 527 \\
\hline Maize & 140 & 120 & 100 & 100 \\
\hline Soybean meal, $47 \%$ & 331 & 310 & 295 & 295 \\
\hline Soybean oil & 25 & 25 & 25 & 25 \\
\hline Coconut fat & - & 15 & 25 & 25 \\
\hline Limestone & 14 & 11 & 10 & 10 \\
\hline Dicalcium phosphate & 11 & 9 & 7 & 7 \\
\hline L-lysine, hydrochloride & 3.5 & 3.0 & 2.5 & 2.5 \\
\hline DL-methionine & 2.5 & 1.5 & 1.5 & 1.5 \\
\hline Sodium bicarbonate & 2.5 & 1 & 1 & 1 \\
\hline Salt & 2.5 & 2.5 & 2.0 & 2.0 \\
\hline Vitamins and mineral, enzyme premix ${ }^{1}$ & 4 & 4 & 4 & 4 \\
\hline \multicolumn{5}{|l|}{ Nutrients (calculated analysis) } \\
\hline Metabolizable energy, $\mathrm{MJ} / \mathrm{kg}$ & 12.98 & 13.31 & 13.48 & 13.48 \\
\hline Crude protein, g/kg & 220 & 210 & 200 & 200 \\
\hline Ether extract, g/kg & 62 & 66 & 68 & 68 \\
\hline Crude fibre, $\mathrm{g} / \mathrm{kg}$ & 35 & 36 & 36 & 36 \\
\hline Ash, g/kg & 47 & 46 & 46 & 46 \\
\hline Calcium, g/kg & 10 & 9 & 8 & 8 \\
\hline Total phosphorus, g/kg & 7 & 6 & 6 & 6 \\
\hline Lysine, $\mathrm{g} / \mathrm{kg}$ & 13 & 12 & 11 & 11 \\
\hline Methionine + cystine, $\mathrm{g} / \mathrm{kg}$ & 10 & 9.6 & 9.4 & 9.4 \\
\hline
\end{tabular}

${ }^{1}$ Composition as presented in Table1.

Morphometric analysis of the small intestine was evaluated according to Giannenas et al. (2011) in 18 chickens from each group. During necropsy of the selected birds, the gastrointestinal tract was removed and the small intestine was divided into three parts: duodenum (from the gizzard outlet to the end of the pancreatic loop); jejunum (from the pancreatic loop to Meckel's diverticulum); and ileum (from Meckel's diverticulum to the ileo-caeco-colic junction). Segments of $1 \mathrm{~cm}$ were taken from the centre of each part and fixed in $10 \%$ buffered formalin for morphometrical assays under light microscopy. Formalin-fixed intestinal tissues were processed, embedded in paraffin wax, sectioned at $3 \mu \mathrm{m}$ and stained, using the haematoxylineosin method. Histological sections were examined with a Zeiss microscope coupled with a Microcomp integrated digital imaging analysis system (Zeiss, Ulm, Germany). Images were viewed with a 4x EPlan objective (40x) to measure morphometric parameters of intestinal architecture. For this purpose, three favourably oriented sections cut perpendicularly from villus enterocytes to the muscularis mucosa were selected from each bird and measurements were carried as follows: villus height was estimated by measuring the vertical distance from the villus tip to villus-crypt junction level for 10 villi per section; and crypt 
depth (the vertical distance from the villus-crypt junction to the lower limit of the crypt) was estimated for 10 corresponding crypts per section.

In order to explain the results of the current study, a further in vitro test was performed to determine the buffering capacity of the experimental diets and their ingredients, using a WTW pH meter (Weilheim, Germany), because buffering capacity could influence the digestion of the feed. A portion of $10 \mathrm{~g}$ feed was placed in a beaker and $100 \mathrm{~mL}$ of distilled water was added. The solution was kept for about 30 min, and then titrated with $0.1 \mathrm{~N} \mathrm{HCl}$, under continuous stirring, to reach pH 4 (Giannenas et al., 2014a). The microlitres of acid consumed were used as units for expressing the buffering capacity of the feeds.

Statistical analysis was performed by one-way analysis of variance using SPSS for Windows (SPSS 2012; Version 20, Chicago, USA). The homogeneity of the variances was tested, and bacteria numbers were log transformed then analysed in order to have better homogeneity of variance. When significant treatment effects were disclosed at probability level of $P<0.05$. Duncan's test was applied to determine statistical differences between means.

\section{Results and Discussion}

Dietary supplementation with a low level of OEO and a high level of attapulgite did not affect $(P>0.05)$ average daily growth, final bodyweight, overall FCR and mortality rate for the blend group or the control group (Table 3). Despite the positive effects of clays on animal health, a high inclusion level (0.6\%) might cause a dilution of energy and protein that could explain their mitigated growth-promoting effect. Another explanation as to whether feed additives might not affect growth performance is that the control performance level is high and may mask growth permission properties of tested feed additives. On the other hand, many factors could influence broiler response to feed additives, such as environment, management and bird characteristics, particularly their genetic potential. In the current trial, mycotoxin levels in both the control and the blend feed were found to be much below reported limits (aflatoxin B1 levels of $0.05 \mathrm{ng} / \mathrm{g}$ with reporting limit of $0.5 \mathrm{ng} / \mathrm{g}$, aflatoxins B2, G1, G2 not detected). Also, the inclusion of OEO at the level of $7.5 \mathrm{mg} / \mathrm{kg}$ of feed was low compared with literature inclusion levels (Windisch et al., 2008). The composition of the microflora was determined on the day of slaughter. In the ileum no significant differences were noted. However, in the caecum increased counts of lactic acid bacteria and reduced counts of coliforms bacteria $(P$ $<0.05$ ) were noted (Table 5). No significant differences were noted in intestinal morphometry in the duodenum, jejunum and ileum compared with the control group (Table 7).

In the second trial, dietary supplementation with a high level of OEO and a low level of attapulgite improved average daily growth, final bodyweight $(P<0.05)$, overall FCR $(P<0.01)$ and mortality rate $(P$ $<0.05$ ) significantly compared with the control birds (Table 4).

The strong antimicrobial effect of OEO compounds, such as phenols, carvacrol and thymol, and terpenes, such as pynene and cymene, may explain this effect. Similarly, it has been shown that essential oil compounds improved the performance of chickens at various levels of supplementation alone (Giannenas et al., 2003; Giannenas et al., 2005; Giannenas et al., 2013) or in combination with organic acids in chicken and turkeys (Giannenas et al., 2014a; 2014b). Similar results were found by Windisch et al. (2008) and Bozkurt et al. (2012), who reported improved weight gain of broilers fed diets supplemented with essential oils, mainly OEO, which are rich in carvacrol and thymol. Also, a diet supplemented with a carvacrol and thymol blend reduced weaning-induced oxidative stress, showed potent free radical scavenging activity and improved growth performance of piglets (Mastelic et al., 2008). Feed additives of various classes have proved increased performance efficiency (Weber et al., 2012), and synergy may be an advantage offered by these combinations. There is limited information about the interaction between essential oils and other nutritional factors (such as nutrient level, type of basal diet, and synergistic or antagonistic effects with other feed additives). In a study conducted to investigate the effects of three doses of individual and combined dietary supplements of specific blends of organic acids and essential oils on broiler performance, Bozkurt et al. (2012) found that a combination of acidifiers and essential oils might allow a lower supplementation level owing to their synergistic effects.

The group fed the blend of high OEO and low attapulgite presented higher counts of lactic acid bacteria and reduced counts of coliform bacteria $(P<0.05)$ in both the ileum and the caecum compared with the control group (Table 6). The blend supplementation with high OEO and low attapulgite gave higher values $(P<0.05)$ of ileal villus height (Table 8). Jamroz et al. (2006) investigated the influence of diet type (corn vs. wheat and barley) on the ability of plant extracts $(100 \mathrm{mg} / \mathrm{kg}$ containing $5 \%$ carvacrol, $3 \%$ cinnamaldehyde and $2 \%$ of capsicum oleoresin) to modify morphological and histochemical characteristics of the stomach and jejunal walls in chickens. Their results showed significantly more jejunal wall villi in chickens fed the maize diet supplemented with plant extracts. The incorporation of carvacrol, cinnamaldehyde and capsicum oleoresin promoted positive and negative changes in digestive function, intestinal epithelium, 
microbial ecology and fermentation in weaned pigs, depending on the amount of protein included in the diet (Manzanilla et al., 2009).

Table 3 Performance results of broiler chickens, $\mathrm{pH}$ values in the digestive tract and diets and buffering capacity of the diets (Trial 1 )

\begin{tabular}{|c|c|c|c|c|}
\hline \multirow{2}{*}{ Item } & \multicolumn{4}{|c|}{ Dietary treatment } \\
\hline & Control & Blend $^{1}$ & SEM $^{2}$ & $P$-value \\
\hline \multicolumn{5}{|l|}{ Body weight, g } \\
\hline $14 \mathrm{~d}$ & 260 & 271 & 11.6 & 0.255 \\
\hline $28 d$ & 1426 & 1471 & 17.6 & 0.168 \\
\hline $35 d$ & 1933 & 1973 & 26.1 & 0.175 \\
\hline $44 \mathrm{~d}$ & 2474 & 2347 & 62.3 & 0.142 \\
\hline Mortality & 4.14 & 4.31 & & 0.155 \\
\hline \multicolumn{5}{|l|}{$\mathrm{FCR}, \mathrm{kg} / \mathrm{kg}$} \\
\hline $14 \mathrm{~d}$ & 1.14 & 1.16 & 0.01 & 0.444 \\
\hline $28 \mathrm{~d}$ & 1.41 & 1.42 & 0.01 & 0.552 \\
\hline $35 d$ & 1.52 & 1.54 & 0.01 & 0.315 \\
\hline $44 \mathrm{~d}$ & 1.69 & 1.66 & 0.05 & 0.166 \\
\hline \multicolumn{5}{|c|}{ Digesta pH (44 d) } \\
\hline Crop & 5.42 & 5.35 & 0.04 & 0.165 \\
\hline Gizzard & 3.31 & 3.33 & 0.04 & 0.252 \\
\hline Ileum & 6.91 & 6.94 & 0.14 & 0.215 \\
\hline Caecum & 7.12 & 7.16 & 0.26 & 0.261 \\
\hline Rectum & 7.05 & 7.09 & 0.08 & 0.266 \\
\hline \multicolumn{5}{|c|}{$\mathrm{pH}$ values of diets } \\
\hline $0-14 d$ & 6.31 & 6.41 & 0.11 & 0.188 \\
\hline $15-8 d$ & 6.15 & 6.26 & 0.07 & 0.112 \\
\hline $29-35 d$ & 6.14 & 6.18 & 0.06 & 0.108 \\
\hline $36-44 d$ & 6.12 & 6.16 & 0.06 & 0.102 \\
\hline \multicolumn{5}{|c|}{ Buffering capacity of diets $\left(\mathrm{mL}^{3}\right)$} \\
\hline $0-14 d$ & $42.2^{b}$ & $51.2^{\mathrm{a}}$ & 2.61 & 0.018 \\
\hline $15-28 d$ & $41.1^{\mathrm{b}}$ & $47.5^{\mathrm{a}}$ & 2.23 & 0.012 \\
\hline $29-35 d$ & $40.2^{b}$ & $46.2^{\mathrm{a}}$ & 2.61 & 0.010 \\
\hline $36-44 d$ & $32.1^{\mathrm{b}}$ & $37.5^{\mathrm{a}}$ & 2.23 & 0.012 \\
\hline
\end{tabular}

\footnotetext{
${ }^{a, b}$ Mean values within a row with different superscript differ significantly at $P<0.05$.

${ }^{1}$ Blend represents group of birds fed the basal diet supplemented with oregano essential oil at a level of 15 $\mathrm{mg} / \mathrm{kg}$ and attapulgite at $6000 \mathrm{mg} / \mathrm{kg}$ of diet, respectively.

${ }^{2}$ SEM: standard error of mean.

${ }^{3} \mathrm{~mL} 0.1 \mathrm{~N} \mathrm{HCl}$ required to acidify $10 \mathrm{~g}$ diet dispersed in $100 \mathrm{~mL}$ distilled water to $\mathrm{pH} 4$.
}

The dietary supplementation of OEO and attapulgite shifted microbiota populations by increasing lactobacillus loads. It has been reported that lactic acid-producing bacteria may improve gastrointestinal function, feed digestibility and animal performance (Rehman et al., 2006). The establishment of Lactobacillus spp. might prevent the colonization of pathogenic bacteria by competitive exclusion (Van der Wielen et al., 2002). Lactobacilli and bifidobacteria compete against potential pathogens for nutrients and binding sites, thereby reducing the intestinal population of non-beneficial bacteria strains. Lactobacilli and bifidobacteria produce organic acids and other bactericidal substances that can suppress the colonization of the intestine 
by non-beneficial bacteria (Jin et al., 1998). It is possible that OEO favoured the growth of lactobacilli and inhibited that of coliforms.

Table 4 Performance results of broiler chickens, $\mathrm{pH}$ values in the digestive tract and diets and buffering capacity of the diets (Trial 2 )

\begin{tabular}{|c|c|c|c|c|}
\hline \multirow{2}{*}{ Item } & \multicolumn{3}{|c|}{ Dietary treatment } & \multirow[b]{2}{*}{$P$-value } \\
\hline & Control & Blend $^{1}$ & SEM $^{2}$ & \\
\hline \multicolumn{5}{|l|}{ Bodyweight, g } \\
\hline $14 \mathrm{~d}$ & 252 & 272 & 12.6 & 0.155 \\
\hline $28 d$ & 1512 & 1566 & 16.6 & 0.145 \\
\hline $35 d$ & 2005 & 2105 & 18.1 & 0.075 \\
\hline $44 d$ & $2355^{\mathrm{b}}$ & $2550^{a}$ & 52.5 & 0.042 \\
\hline Mortality & $3.62^{\mathrm{a}}$ & $3.01^{\mathrm{b}}$ & & 0.005 \\
\hline \multicolumn{5}{|l|}{$\mathrm{FCR}, \mathrm{kg} / \mathrm{kg}$} \\
\hline $14 \mathrm{~d}$ & 1.11 & 1.06 & 0.01 & 0.244 \\
\hline $28 d$ & 1.46 & 1.41 & 0.01 & 0.252 \\
\hline $35 d$ & $1.55^{\mathrm{a}}$ & $1.46^{\mathrm{b}}$ & 0.01 & 0.005 \\
\hline $44 d$ & $1.81^{\mathrm{a}}$ & $1.70^{\mathrm{b}}$ & 0.05 & 0.004 \\
\hline \multicolumn{5}{|c|}{ Digesta pH (44 d) } \\
\hline Crop & 5.41 & 5.35 & 0.05 & 0.165 \\
\hline Gizzard & 3.23 & 3.24 & 0.04 & 0.252 \\
\hline Ileum & 6.82 & 6.76 & 0.14 & 0.215 \\
\hline Caeca & 7.11 & 7.02 & 0.26 & 0.261 \\
\hline Rectum & 7.01 & 6.89 & 0.06 & 0.266 \\
\hline \multicolumn{5}{|c|}{$\mathrm{pH}$ values of diets } \\
\hline $0-14 d$ & 6.35 & 6.22 & 0.15 & 0.122 \\
\hline $15-28 d$ & 6.26 & 6.22 & 0.08 & 0.212 \\
\hline $29-35 d$ & 6.38 & 6.22 & 0.19 & 0.133 \\
\hline $36-44 d$ & 6.26 & 6.19 & 0.12 & 0.144 \\
\hline \multicolumn{5}{|c|}{ Buffering capacity of diets $\left(\mathrm{mL}^{3}\right)$} \\
\hline $0-14 d$ & 44.2 & 45.4 & 2.61 & 0.177 \\
\hline $15-28 d$ & $42.5^{b}$ & $44.1^{\mathrm{a}}$ & 1.23 & 0.000 \\
\hline $29-35 d$ & $41.2^{b}$ & $42.2^{\mathrm{a}}$ & 1.23 & 0.001 \\
\hline $36-44 d$ & $40.5^{b}$ & $42.1^{\mathrm{a}}$ & 1.61 & 0.000 \\
\hline
\end{tabular}

$\overline{a, b}$ Mean values within a row with superscripts differ significantly at $P<0.05$.

${ }^{1}$ Blend represents group of birds fed the basal diet supplemented with oregano essential oil at a level of 30 $\mathrm{mg} / \mathrm{kg}$ and attapulgite at $3000 \mathrm{mg} / \mathrm{kg}$ of diet, respectively.

${ }^{2}$ SEM: standard error of mean.

${ }^{3} \mathrm{~mL} 0.1 \mathrm{~N} \mathrm{HCl}$ required to acidify $10 \mathrm{~g}$ diet dispersed in $100 \mathrm{~mL}$ distilled water to $\mathrm{pH} 4$.

The intestinal villus may be regarded as the capacity of the bird to absorb nutrients. Longer villi are typically associated with excellent gut health and high absorptive efficiency (Garcia et al., 2007). The structure of the intestinal mucosa may reveal several stressors that are present in the digesta and may lead to relatively quick changes in the intestinal mucosa, owing to the close proximity of the mucosal surface and the intestinal content. Changes in intestinal morphology, such as shorter villi and deeper crypts, have been associated with the presence of toxins and higher tissue turnover (Miles et al., 2006). 
Table 5 Intestinal microbiota on the ileum and caecum of 44-day-old broiler chickens fed a low inclusion level of oregano essential oil (OEO) and a high level of attapulgite (Trial)

\begin{tabular}{ccccc}
\hline Ileum (cfu/g) & Control & Blend $^{\mathbf{1}}$ & SEM & $P$-value \\
\hline Total aerobes & $3.89 \times 10^{6}$ & $3.38 \times 10^{6}$ & 0.166 & 0.335 \\
Total anaerobes & $3.20 \times 10^{7}$ & $9.80 \times 10^{7}$ & 0.244 & 0.151 \\
Total coliforms & $2.84 \times 10^{3}$ & $4.04 \times 10^{3}$ & 0.155 & 0.105 \\
Lactobacilli spp. & $1.47 \times 10^{7}$ & $3.64 \times 10^{7}$ & 0.142 & 0.106 \\
Caecum (cfulg) & & & & \\
Total aerobes & $2.74 \times 10^{8}$ & $1.28 \times 10^{8}$ & 0.125 & 0.555 \\
Total anaerobes & $5.38 \times 10^{8}$ & $4.37 \times 10^{8}$ & 0.126 & 0.443 \\
Total coliforms & $2.78 \times 10^{6} \mathrm{a}$ & $3.66 \times 10^{5 \mathrm{~b}}$ & 0.054 & 0.005 \\
Lactobacilli spp. & $2.78 \times 10^{7 \mathrm{~b}}$ & $2.83 \times 10^{8 \mathrm{a}}$ & 0.042 & 0.005
\end{tabular}

${ }^{a, b}$ Mean values within a row with different superscripts differ significantly at $P<0.05$.

${ }^{1}$ Blend represents group of birds fed the basal diet supplemented with OEO at a level of 15 and attapulgite at 6000 $\mathrm{mg} / \mathrm{kg}$ of diet, respectively.

2 SEM: standard error of mean.

Table 6 Intestinal microbiota in the ileum and caecum of 44-day-old broiler chickens fed a high inclusion level of oregano essential oil (OEO) and a low level of attapulgite (Trial 2)

\begin{tabular}{|c|c|c|c|c|}
\hline Ileum (cfu/g) & Control & Blend $^{1}$ & SEM & $P$-value \\
\hline Total aerobes & $6.06 \times 10^{8}$ & $1.19 \times 10^{8}$ & 0.073 & 0.255 \\
\hline Total anaerobes & $1.81 \times 10^{7}$ & $1.96 \times 10^{7}$ & 0.122 & 0.355 \\
\hline Total coliforms & $2.91 \times 10^{4 \mathrm{a}}$ & $5.22 \times 10^{2 \mathrm{~b}}$ & 0.077 & 0.009 \\
\hline Lactobacilli spp. & $3.86 \times 10^{6} \mathrm{~b}$ & $2.88 \times 10^{7 a}$ & 0.102 & 0.005 \\
\hline \multicolumn{5}{|l|}{ Caecum (cfu/g) } \\
\hline Total aerobes & $1.02 \times 10^{6 \mathrm{~b}}$ & $1.82 \times 10^{8 \mathrm{a}}$ & 0.123 & 0.005 \\
\hline Total anaerobes & $5.20 \times 10^{7}$ & $4.37 \times 10^{7}$ & 0.129 & 0.314 \\
\hline Total coliforms & $7.67 \times 10^{7 a}$ & $2.67 \times 10^{6 \mathrm{~b}}$ & 0.107 & 0.006 \\
\hline Lactobacilli spp. & $5.55 \times 10^{6 \mathrm{~b}}$ & $4.07 \times 10^{7 \mathrm{a}}$ & 0.086 & 0.005 \\
\hline
\end{tabular}

Aromatic plants and essential oils are known to exert antibacterial, antifungal and antiviral activity in in vitro experiments (Windisch et al., 2008). It is accepted that essential oils are slightly more active against gram-positive than gram negative bacteria (Brenes \& Roura, 2010). The essential oils showed dosedependent effects on cell integrity, as measured with propidium iodide, of gram-positive bacteria. However, growth inhibition of gram-negative bacteria occurred mostly without cell integrity loss (Thapa et al., 2012). Comparable in vivo studies found inhibiting effects against pathogens such as Clostridium perfringens, E. coli and Eimeria species (Bozkurt et al., 2013). The controlled pathogen load contributed to healthy microbial metabolites, improved intestinal integrity and protection against enteric disease (Bozkurt et al., 2013). Attention should be paid to the potential negative effects induced by essential oils on healthy intestinal bacteria. Horošová et al. (2006) reported that OEO exhibited a strong bactericidal effect against Lactobacilli isolated from faecal samples of chickens fed diets with oregano. In an in vivo anti-bacterial study, Thapa et al. (2012) concluded that beneficial commensal Faecalibacterium rausnitzii was sensitive to essential oils at similar or even lower concentrations than the pathogens. In addition, Cross et al. (2007) and 
Muhl \& Liebert (2007) reported that essential oils had no effect on the microbial population and composition in the digestive tract or faecal excretions of broilers.

Table 7 Intestinal morphology of 44-day-old broiler chickens fed a low inclusion level of oregano essential oil (OEO) and a high level of attapulgite (Trial 1)

\begin{tabular}{lcccc}
\hline Duodenum & Control & Blend $^{\mathbf{1}}$ & SEM $^{2}$ & P-value \\
\hline Villus height $(\mu \mathrm{m})$ & 1910.4 & 1986.4 & 41.6 & 0.098 \\
Crypt depth $(\mu \mathrm{m})$ & 181.4 & 182.0 & 10.6 & 0.216 \\
$\quad$ Villus height to crypt depth ratio & 10.5 & 10.9 & 0.26 & 0.116 \\
Jejunum & & & & \\
$\quad$ Villus height $(\mu \mathrm{m})$ & 1457.7 & 1501.1 & 47.3 & 0.144 \\
$\quad$ Crypt depth $(\mu \mathrm{m})$ & 141.1 & 144.1 & 10.4 & 0.234 \\
Villus height to crypt depth ratio & 10.3 & 10.4 & 0.28 & 0.145 \\
Ileum & & & & \\
Villus height $(\mu \mathrm{m})$ & 945.3 & 992.7 & 33.6 & 0.131 \\
Crypt depth $(\mu \mathrm{m})$ & 121.5 & 114.8 & 11.2 & 0.114 \\
Villus height to crypt depth ratio & 7.78 & 8.64 & 1.02 & 0.255
\end{tabular}

\footnotetext{
${ }^{1}$ Blend represents group of birds fed the basal diet supplemented with OEO at a level of $15 \mathrm{mg} / \mathrm{kg}$ and attapulgite at $6000 \mathrm{mg} / \mathrm{kg}$ of diet, respectively.

${ }^{2}$ SEM: standard error of mean.
}

Table 8 Intestinal morphology of 44-day-old broiler chickens fed a high inclusion level of oregano essential oil (OEO) and a low level of attapulgite (Trial 2)

\begin{tabular}{|c|c|c|c|c|}
\hline Duodenum & Control & Blend $^{1}$ & $\mathrm{SEM}^{2}$ & $P$-value \\
\hline Villus height $(\mu \mathrm{m})$ & 1804.4 & 1892.4 & 44.5 & 0.113 \\
\hline Crypt depth $(\mu \mathrm{m})$ & 179.4 & 185.0 & 9.56 & 0.236 \\
\hline Villus height to crypt depth ratio & 9.14 & 10.23 & 0.66 & 0.124 \\
\hline \multicolumn{5}{|l|}{ Jejunum } \\
\hline Villus height $(\mu \mathrm{m})$ & 1602.6 & 1531.3 & 37.3 & 0.242 \\
\hline Crypt depth $(\mu \mathrm{m})$ & 180.9 & 217.8 & 15.6 & 0.433 \\
\hline Villus height to crypt depth ratio & 8.46 & 7.03 & 0.29 & 0.124 \\
\hline \multicolumn{5}{|l|}{ Ileum } \\
\hline Villus height $(\mu \mathrm{m})$ & $932.3^{b}$ & $1024.5^{\mathrm{a}}$ & 23.6 & 0.031 \\
\hline Crypt depth $(\mu \mathrm{m})$ & 121.5 & 128.3 & 10.2 & 0.076 \\
\hline Villus height to crypt depth ratio & 7.67 & 7.98 & 0.66 & 0.077 \\
\hline
\end{tabular}

The inconsistency of blend application, especially in terms of growth performance, might be because of differences in the buffering capacity value of the diets. The buffering capacity value, indicating the amount of acid needed to lower the $\mathrm{pH}$ of a feed to a certain value, is important because it affects the course of digestion. High buffering capacity values in feeds pose higher risks for young animals, which have limited capacity to secrete gastric acid. When using feeds with high buffering capacity, the gastric $\mathrm{pH}$ remains high, impairing protein digestibility. Undigested protein reaches the lower digestive tract where excessive protein fermentation may occur, leading to formation of toxic biogenic amines. In addition, poultry feeds with high 
buffering capacity may result in proliferation of non-beneficial bacteria in the digestive tract (Giannenas et al., 2014a; 2014b). In Tables 3 and 4 it is shown that the source used to supply the mineral requirements to the broiler diets could largely influence their acidic/basic balance and, consequently, their buffering capacity. Limestone, sodium bicarbonate and trace-mineral premix exhibited very high buffering capacities compared with those of the single feedstuffs and attapulgite exhibited a high buffering capacity compared with the single feedstuffs while dicalcium phosphate showed lower buffering capacity. These findings suggest that the buffering capacity of poultry diets could be readily manipulated by varying the type and proportion of the inorganic mineral sources (Partanen et al., 2002). Such an approach might deserve further investigation as it could be a low-cost alternative to reduce the buffering capacity of feeds (Giannenas et al., 2014a; 2014b). However, the $\mathrm{pH}$ values in the digestive tract were similar among the experimental groups for crop, gizzard, ileum and rectum.

Attapulgite is a crystalloid hydrous magnesium-aluminium silicate mineral with a special laminated chain structure in which crystalline lattice displacement exists. Thus, the crystals contain varying quantities of $\mathrm{Na}^{+}, \mathrm{Ca}^{2+}, \mathrm{Fe}^{3+}$ and $\mathrm{Al}^{3+}$, and are present as needles, fibres or fibrous clusters. Attapulgite has very good colloidal properties with features such as dispersion, high temperature endurance, salt and alkali resistance, and high adsorbing and decolouring capabilities. Attapulgite has certain plastic and adhesive characteristics. Although it is a relatively low-cost composting amendment, its effects in combination with OEO are limited (Kaya et al., 2013). A previous study showed that attapulgite, zeolite or another absorbent could reduce ammonia loss by about $50 \%$ in the animal manure aerobic composting process by reducing ammonia volatilization (Lefcourt \& Meisinger, 2001; Xie et al., 2012). Therefore, the modified attapulgite has much stronger absorptivity features (the surface area has increased by 300 times that of common attapulgite) and can promote digestion better.

The search for alternatives to antibiotics has generated considerable interest in recent years with an emphasis on herbs and essential oils and their beneficial effects for animal production (Windisch et al., 2008; Giannenas et al., 2013; Zeng et al., 2015). Although most of the latest research has noted the major components and original sources of essential oils in in vivo trials, only a few papers have identified the quantity of the principle components. In addition, Brenes \& Roura (2010) argued that minor components are critical to the activity of essential oils and may have a synergistic influence. Therefore, the detailed constituents of essential oils need to be determined in order to assess their various biological effects. In this way, it may be possible to compare different essential oil products and formulate mixtures that optimize their efficacy.

\section{Conclusions}

Feed additives such as essential oils, and in combination with zeolites, may offer effective tools to improve the growth performance of broiler chickens. The results of the current study suggest that the combination of $15 \mathrm{mg} \mathrm{OEO} / \mathrm{kg}$ and $2.4 \mathrm{~g}$ attapulgite $/ \mathrm{kg}$ exerted a positive effect on growth performance, ileal villus height and intestinal microbiota for broilers. However, further research is needed to establish this suggestion through more extensive investigation on feed digestion and growth performance of challenged chicken with bacteria or protozoa that cause severe intestinal diseases.

\section{Acknowledgements}

This work was supported by the project GreenPoultry, funded by the national action COOPERATION 2011 Partnerships of Production and Research Institutions, of the NSRF 2007-013 Operational Programme Competitiveness and Entrepreneurship, General Secretariat for Research and Technology, Ministry of Education and Religious Affairs.

\section{Authors' contributions}

IG, TB, IS, PP conceived and designed the experiments. IS, AT, IG performed the experiment and data analysis. DT performed the intestinal histology analysis. AT performed the intestinal flora analysis IG, and IS wrote the manuscript. All authors commented on early and final versions of the manuscript.

\section{Conflict of interest declaration}

The authors declare that they have no conflict of interest.

\section{References}

Bozkurt, M., Küçükyilmaz, K., Çatli, A.U., Çinar, M., Çabuk, M. \& Alçiçek, A., 2012. Effects of administering an essential oil mixture and an organic acid blend separately and combined to diets on broiler performance. Arch. Geflugelkd. 76, 81-87.

Bozkurt, M., Giannenas, I., Küçükyilmaz, K., Christaki, E. \& Florou-Paneri, P., 2013. An update on approaches to controlling coccidia in poultry using botanical extracts. Br. Poult. Sci. 54, 713-727.

Brenes, A. \& Roura, E., 2010. Essential oils in poultry nutrition: Main effects and modes of action. Anim. Feed Sci. Technol. 158, 1-14. 
Castanon, J.I.R., 2007. History of the use of antibiotic as growth promoters in European poultry feeds. Poult. Sci. 86, 2466-2471.

Clark, S., Daly, R., Jordan, E., Lee, J., Mathew, A. \& Ebner, P., 2012. Extension education symposium: the future of biosecurity and antimicrobial use in livestock production in the United States and the role of extension. J. Anim. Sci. 90, 2861-2872.

Cross, D.E., McDevitt, R.M., Hillman, K. \& Acamovic, T., 2007. The effect of herbs and their associated essential oils on performance, dietary digestibility and gut microflora in chickens from 7 to 28 days of age. Br. Poult. Sci. 48, 496-506.

Franz, C., Baser, K.H.C. \& Windisch, W., 2010. Essential oils and aromatic plants in animal feeding - a European perspective. A review. Flavour Frag. J. 25, 327-340.

Garcia, V., Catala-Gregori, P., Hernandez, F., Megias, M. \& Madrid, J., 2007. Effect of formic acid and plant extracts on growth, nutrient digestibility, intestine mucosa morphology, and meat yield of broilers. J. Appl. Poult. Res. 16, 555-562.

Giannenas, I., Florou-Paneri, P., Papazahariadou, M., Christaki, E., Botsoglou, N.A. \& Spais, A.B., 2003. Effect of dietary supplementation with oregano essential oil on performance of broilers after experimental infection with Eimeria tenella. Arch. Anim. Nutr. 57, 99-106.

Giannenas, I., Florou - Paneri, P., Botsoglou, N., Christaki, E. \& Spais, A.B., 2005. Effect of supplementing feed with oregano and/or a-tocopheryl acetate on growth of broiler chickens and oxidative stability of meat. J. Anim. Feed Sci. 14, 521-535.

Giannenas, I., Tsalie, E., Chronis, E., Mavridis, S., Tontis, D. \& Kyriazakis, I., 2011. Consumption of Agaricus bisporus mushroom affects the performance, intestinal microbiota composition and morphology, and antioxidant status of turkey poults. Anim. Feed Sci. Technol. 165, 218-229.

Giannenas, I., Bonos, E., Christaki, E. \& Florou-Paneri, P., 2013. Essential oils and their applications in animal nutrition. Med. Aromat. Plants. 2, 1-12.

Giannenas, I.A., Papaneophytou, C.P., Tsalie, E., Triantafillou, E., Tontis, D. \& Kontopidis, G.A., 2014a. The effects of benzoic acid and essential oil compounds in combination with protease on the performance of chickens. J. Anim. Feed Sci. 23, 73-81.

Giannenas, I., Papaneophytou, C., Tsalie, E., Mavridis, S., Triantafillou, E., Kontopidis, G. \& Tontis, D., 2014b. Effect of benzoic acid and essential oil compounds on performance of turkeys, intestinal microbiota, intestinal morphology and antioxidant status. Asian Australas. J. Anim. Sci. 27, 225-236.

Horošová, K., Bujňáková, D. \& Kmet', V., 2006. Effect of oregano essential oil on chicken Lactobacilli and E. coli. Folia Microbiol. 51, 278-280.

Jamroz, D., Wertelecki, T., Houszka, M. \& Kamel, C., 2006. Influence of diet type on the inclusion of plant origin active substances on morphological and histochemical characteristics of the stomach and jejunum walls in chicken. J. Anim. Physiol. Anim. Nutr. 90, 255-268.

Jin, L.Z., Ho, Y.W., Abdullah, N. \& Jalaludin, S., 1998. Growth performance, intestinal microbial populations, and serum cholesterol of broilers fed diets containing lactobacillus cultures. Poult. Sci. 77, 1259-1265.

Kaya, D.A., Vuluga, Z., Nicolae, C.A., Radovici, C. \& Albu, M.G., 2013. The properties of two natural zeolites modified with oregano essential oil. Rev. Rom. Mater. 43, 48-54.

Lam, A. \& Rivera, A., 2006. Theoretical study of the interaction of surfactants and drugs with natural zeolite. Micropor. Mesopor. Mat. 91, 181-186.

Lefcourt, A.M. \& Meisinger, J.J., 2001. Effect of adding alum or zeolite to dairy slurry on ammonia volatilization and chemical composition. J. Dairy Sci. 84, 1814-1821.

Maenner, K., Vahjen, W. \& Simon, O., 2011. Studies on the effects of essential-oil-based feed additives on performance, ileal nutrient digestibility, and selected bacterial groups in the gastrointestinal tract of piglets. J. Anim. Sci. 89, 2106-2112.

Manzanilla, E.G., Pérez, J.F., Martín, M., Blandón, J.C., Baucells, F., Kamel, C. \& Gasa, J., 2009. Dietary protein modifies effect of plant extracts in the intestinal ecosystem of the pig at weaning. J. Anim. Sci. 87, 2029-2037.

Mastelic, J., Jerkovic, I., Blazevic, I., Poljak-Blazi, M., Borovic, S., Ivancic-Bace, I., Smrecki, V., Zarkovic, N., BrcicKostic, K., Vicic-Topuc, D. \& Mueller, N., 2008. Comparative study on the antioxidant and biological activities of carvacrol, thymol, and eugenol derivatives. J. Agric. Food Chem. 56, 3989-3996.

Miles, R.D., Butcher, G.D., Henry, P.R. \& Littell, R.C., 2006. Effect of antibiotic growth promoters on broiler performance, intestinal growth parameters, and quantitative morphology. Poult. Sci. 85, 476-485.

Muhl, A. \& Liebert, F., 2007. Growth and parameters of microflora in intestinal and faecal samples of piglets due to application of a phytogenic feed additive. J. Anim. Physiol. Anim. Nutr. 91, 411-418.

NRC, 1994. Nutrient Requirements of Poultry. 9th rev. ed. National Research Council, National Academy Press, Washington, D.C., USA.

NRC, 1996. Guide for the Care and Use of Laboratory Animals. Institute of Laboratory Animal Resources. Commission on Life Sciences, National Research Council, National Academy Press, Washington, D.C., USA.

Pappas, A., Zoidis, E., Theophilou, N., Zervas, G. \& Fegeros, K., 2010. Effects of palygorskite on broiler performance, feed technological characteristics and litter quality. Appl. Clay Sci. 49, 276-280.

Partanen, K., Siljander-Rasi, H., Alaviuhkola, T., Suomi, K. \& Fossi, M., 2002. Performance of growing-finishing pigs fed medium- or high-fibre diets supplemented with avilamycin, formic acid or formic acid-sorbate blend. Livest. Prod. Sci. 73, 139-152.

Pratt, R., Barton, M. \& Hart, W., 2003. Antibiotic resistance in animals. Communicable Diseases Intelligence Quarterly Report [online] 27, 121-126. 
Rehman, H., Böhm, J. \& Zentek, J., 2006. Effects of diets with insulin and sucrose on the microbial fermentation in the gastrointestinal tract of broilers. Proc. Soc. Nutr. Physiol. 15, 155-158.

Symeon, G.K., Zintilas, C., Demiris, N., Bizelis, L.A. \& Deligeorgis, S.G., 2010. Effects of oregano essential oil dietary supplementation on the feeding and drinking behaviour as well as the activity of broilers. Int. J. Poult. Sci. 9, 401-405.

SPSS manual, 2012. Version 20.0 for Windows. SPSS Inc., Chicago, IL, USA.

Thapa, D., Losa, R., Zweifel, B. \& John Wallace, R., 2012. Sensitivity of pathogenic and commensal bacteria from the human colon to essential oils. Microbiology 158, 2870-2877.

Van der Wielen, P.W.J.J., Lipman, L.J.A., Van Knapen, F. \& Biesterveld, S., 2002. Competitive exclusion of Salmonella enterica serovar enteritidis by Lactobacillus crispatus and Clostridium lactatifermentans in a sequencing fed-batch culture. Appl. Environ. Microbiol. 68, 555-559.

Vogt, H., Harnisch, S., Rauch, H.W. \& Heil, G., 1989. Dried natural spices in broiler rations. Arch. Geflugelkd. 53, 144-150.

Weber, G.M., Michalczuk, M., Huyghebaert, G., Juin, H., Kwakernaak, C. \& Gracia, M.I., 2012. Effects of a blend of essential oil compounds and benzoic acid on performance of broiler chickens as revealed by a meta-analysis of 4 growth trials in various locations. Poult. Sci. 91, 2820-2828.

Wegener, H., Aarestrup, F., Jensen, L., Hammerum, A.M. \& Bager, F., 1998. The association between the use of antimicrobial growth promoters and development of resistance in pathogenic bacteria towards growth promoting and therapeutic antimicrobials. Anim. Feed Sci. Technol. 7, 7-14.

Windisch, W., Schedle, K., Plitzner, C. \& Kroismayr, A., 2008. Use of phytogenic products as feed additives for swine and poultry. J. Anim. Sci. 86, 140-148.

Xie, K., Jia, X., Xu, P., Huang, X., Gu, W., Zhang, F., Yang, S. \& Tang, S., 2012. The addition of modified attapulgite reduces the emission of nitrous oxide and ammonia from aerobically composted chicken manure. J. Air Waste Manag. Assoc. 62, 1174-1181.

Zeng, Z., Zhang, S., Wang, H. \& Piao, X., 2015. Essential oil and aromatic plants as feed additives in non-ruminant nutrition: a review. J. Anim. Sci. Biotechnol. 6, 015-0004. 